\title{
Shaut Al-'Arabiyah
}

P-ISSN : 2354-564X; E-ISSN : 2550-0317

Vol. 9 No. 1, Juni 2021

DOI : $10.24252 /$ saa.v9i1.21493

\section{النعت والثو كيد}

\section{Abudzar Al Qifari ${ }^{1}$}

${ }^{1}$ Fakultas Tarbiyah dan keguruan UIN Alauddin Makassar

E-mail : abusokganteng@gmail.com ${ }^{1}$

Abstrak : Jika na'at adalah ism jamid (beku, tidak mengalami perubahan) maka, ada 9 bentuk: Al-masdar (اسم الأشارة) (اسو) Dzu (المصدر) Ism isyarah dzāti (ذات) yang bermakna memiliki/mempunyai (صاحب). Ism mausul yang diganti dengan al (اسم الموصول المقترن بال). Menunjukkan berbilangnya yang disifati. Ism yang menyerupai yā al-nisbah (الاسم الذي لحتته ياء النسبة). Menunjukkan

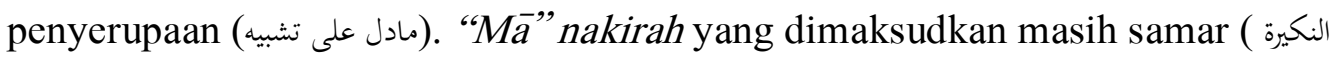

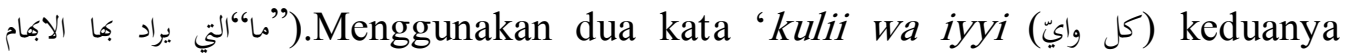
menunjukkan atas kesempurnaan yang disifati bagi sifat. Al-na'at pada ism marfu, diserupakan dengan timbangan af'al, dan al na'at pada damir dan ism 'alam.

Abstract : If na'at is ism jamid (frozen, does not change) then, there are 9 forms: Al-masdar (المصدر), Ism isyarah (اسم الأشارم). Dzu (ذو) or dzäti (ذات)

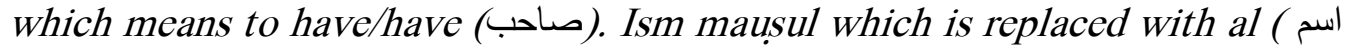
(الموصول المقترن ال Shows the number of attributes. Ism that resembles yā al-

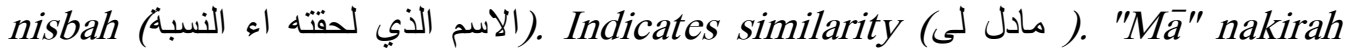
which is meant is still vague (النكيرة التي اد ا الابهام “ما (الإ)" Using the two words 'kulii wa iyyi (كل ( S) both indicate the perfection that is inherent in the nature. Al-na'at in ism marfu, is likened to af'al scales, and al-na'at in damir and ism'alam.

Kata kunci: Al-na'at; syibh al-jumlah 
النعت والنو كيد

\section{PENDAHULUAN}

Al-Lugah al-'Arabiyyah merupakan bahasa yang sangat penting untuk dipelajari dan diketahui apalagi yang mengaku sebagai orang yang menganut agama Islam. Bahkan, wajib hukumnya untuk memahami bahasa tersebut untuk diamalkan dalam kehidupan sehari-hari. Salah satu tanda wajibnya, dalam shalat orang Islam wajib membaca ayat-ayat al-Qur'an yakni surah al-Fätihah.

Sumber pengetahuan umat Islam adalah al-Qur'an dan hadis. Keduanya berbahasa arab sesuai tempat diturunkannya. Memahami keduanya tidaklah mudah, itu dikarenakan bahasa kita berbeda dengan mereka. Kitab-kitab rujukan yang merupakan penjabaran hukum dari keduanya pun berbahasa arab. Oleh karena itu, untuk memudahkan bangsa lain dalam memahaminya, dikembangkanlah suatu disiplin ilmu tata bahasa arab, yaitu nahwu dan șarf ( النحو و الصرف).

Ilmu ini sudah ada pada zaman al-khulafa' al-rāsyidin . Ketika Khalifah Ali bin Abi Talib mengambil kebijaksanaan dengan memerintahkan panglimanya Abu Aswad alDuwaliy untuk menyusun kaidah-kaidah bahasa arab, yang kemudian menjadi dasar acuan bagi pembacaan ayat-ayat al-Qur'an. Kebijaksanaan khalifah tersebut dianggap sebagai perintis lahirnya ilmu nahwu dan i'rab al-Qur'ān. ${ }^{1}$

Salah satu cabang ilmu nahwu adalah al-na'at dan al-taukid. Al-na'at dan al-taukid adalah bagian dari al-tābi', yaitu mengikuti yang diikutinya dalam I'rab. Dalam pembahasan ini akan dijelaskan tentang al-na'at dan al-taukid tersebut.

\section{PEMBAHASAN}

\section{A. Pengertian Al-Na'at}

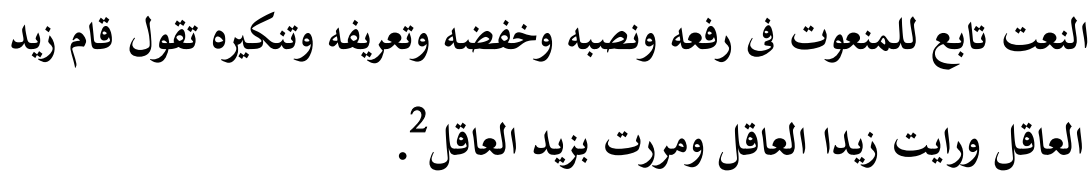

Artinya:

Na'at (sifat) itu adalah mengikuti kepada yang diikutinya (man'utnya) pada rafa', nasab, dan khafachya (jamya), ma'rifatnya dan nakirahnya, seperti :

Rafa': قام زيد العاقل (Zaid yang berakal telah berdiri)

(saya melihat zaid yang berakal)

Khafad (jar) مررت بزيد العاقل (saya bertemu dengan zaid yang berakal).

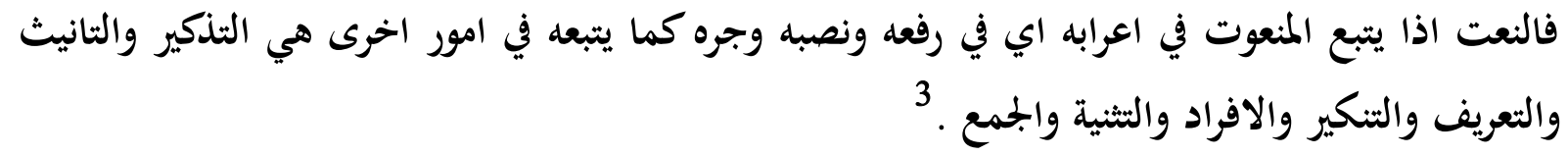

\footnotetext{
${ }^{1}$ Mardan, Al-Qur'ān ( Sebuah Pengantar Memahami al-Qur'ān Secara Utuh) (Cet. I; Makassar: Alauddin Press, 2009), h. 22.

${ }^{2}$ Muhammad Mahy al-Dīn 'Abd al-Hamīi, al-Tahfat al-Saniyah bi Syarh al-Muqaddimah al-Jurümiyah (Beirut: al-Maktabah al-'Așriyah, t.th), h. 107.

${ }^{3}$ Muhammad 'Abd al-Rahīm 'Ads, al-Wādih fì Qawāid al-Nahw wa al-Ṣarf (Cet. I; Amman: Dār Majdilāwi, 1991), h. 185.
} 
Artinya:

Al-na'at adalah mengikuti man'ut dalam i'rab yaitu rafa', jika man'ut itu rafa'; nasab, jika man'utnya mansub; jar, jika man'utnya jar, demikian juga dalam bentuk lain, lakilaki, jka man'utnya laki-laki; perempuan, jika man'utnya perempuan; ma'rifah, jika man'utnya ma'rifah; nakirah, jika man'utnya nakirah; tunggal, jika man'utnya juga tunggal; dua, jika man'utnya dua dan jamak, jika man'utnya jamak.

Manfaat al-na'at untuk membedakan antara yang berkongsi dalam ism. Jika yang disifati itu ma’rifah (علي) maka fungsi al-na'at (المجتهد) sebagai penjelas, contoh جاء علي) (الججنهد. Jika yang disifati itu nakirah (رجلاً), maka fungsi al-na'at (عاقلاً) sebagai pengkhususan, contoh صاحب رجلاً عاقلاً.

\section{B. Ketentuan-ketentuan Al-Na'at}

1. Al-na'at al-mufrad, al-jumlah dan syibh al-jumlah

a. Al-na'at al-mufrad adalah wajib adanya adalah ism musytaq, at au yang dimulai ism mustaq. Di antara ism-ism yang menjadikan na'at karena dimulai ism mustaq:

(a) ism isyarah (اسم الأشارة) contoh, أسالت الطالب هذا

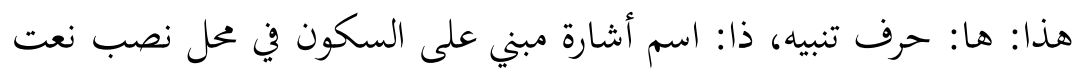

نجح الطالب الذي اجتهد، (b) ism mausul yang dimulai dengan hamzah waṣl, contoh

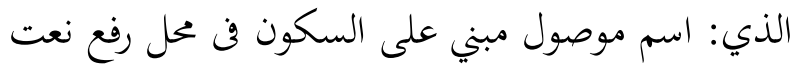

افأت طلابا خمسة (العدد), contoh) berbilang

خمسة: نعت منصوب بالفتحة الظاهرة

b. Al-na'at jumlah adalah na'at yang terdiri dari jumlah ismiah atau fi'liah.

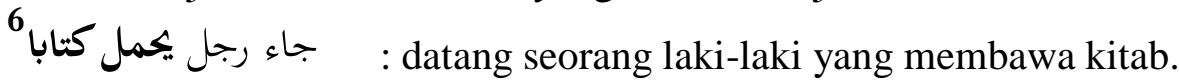

c. Al-na'at syibh al-jumlah adalah na'at yang terdiri dari zaraf( زمان او المكان) atau jar al- majrur. Contoh, 7 di dalam rumah seorang laki-laki yang berada di depan kursi.

Tidak terjadi na'at jumlah bagi ma'rifah akan tetapi, na'at terjadi bagi nakirah. Jika na'at diletakkan sesudah ma’rifah maka dia berfungsi sebagai hāl, contoh جاء علي يحمل كتابا :datang Ali dengan membawa kitab. عليadalah ma’rifah, يحمل كتابا adalah jumlah.

Al-Na'at al-jumlah bisa terjadi pada ma'rifah jika setelah ma'rifah diberi al jinsiyah secara makna adalah nakirah dan dijadikan sebagai hāl. Dari segi lafadz, ia

222.

${ }^{4}$ Musțafā al-Galāyainī, Jāmi’ al-Durūs al-'Arabiyah, juz 3 ( Beirut: al-Maktabah al-'Așriyah, t.th), h.

5،Abduh al-Rājiḥī, al-Tațiq al-Nahwuyi (Cet. I: Riyad; Maktabah al-Mā’rif, 1999), h. 376

${ }^{6}$ Musțafā al-Galāyainī, op. cit., h. 226.

${ }^{7}$ Ibid. 
dima'rifakan secara lafadz dengan al (بال). Contoћ, لال تخالط الرجل يعمل عمل السفهاء:jangan kamu campur adukkan seseorang yang mengerjakan perbuatan orang bodoh. ${ }^{8}$

2. Al-na'at pada ism marfu, diserupakan dengan timbangan af'al, dan al na'at pada damir dan ism 'alam.

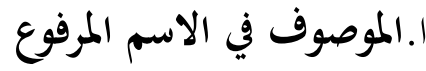

$$
\begin{aligned}
& \text { امثلة للمؤنث: } \\
& \text { امثلة للمنكى : } \\
& \text { المفردة العاقلة (معرفة) } \\
& \text { المفرد العاقل (معرفة) } \\
& \text { تنجح الطالبة الذكية في الامتحان } \\
& \text { ينجح الطالب الذكي في الامتحان } \\
& \text { المفردة العاقلة (نكيرة) } \\
& \text { المفرد العاقل (نكيرة) } \\
& \text { تنجح طالبة ذكية في الامتحان } \\
& \text { المثني المؤنث (معرفة) } \\
& \text { المثني العاقل (معرفة) } \\
& \text { تنجح الطالبتان الذكيتان في الامتحان } \\
& \text { ينجح الطالبان الذكيان في الامتحان }
\end{aligned}
$$

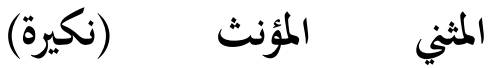

$$
\begin{aligned}
& \text { المثني العاقل (نكيرة) } \\
& \text { تنجح } \\
& \text { ينجح طالبان ذكيان في الامتحان } \\
& \text { الجمع المؤنث (معرفة) } \\
& \text { حضرت الموظفات النشيطات } \\
& \text { الجمع المؤنث (نكيرة) } \\
& \text { حضرت موظفات نشيطان } \\
& \text { المفرد المؤنث (معرفة) } \\
& \text { تحطمت السيارة الكبيرة } \\
& \text { المفرد المؤنث (نكيرة) } \\
& \text { تحطمت سيارة كبيرة }
\end{aligned}
$$


النعت والثو كيد

$$
\begin{aligned}
& \text { الجمع المؤنث (معرفة) } \\
& \text { نزلت الطائرات الكبيرة } \\
& \text { الجمع المؤنث (نكيرة) } \\
& \text { نزلت طائرات كبيرة. } 9 \\
& \text { الجمع لغير الغاقل (معرفة) } \\
& \text { نزلت الامطار العزيزة } \\
& \text { الجمع لغير العاقل (نكيرة) } \\
& \text { نزلت امطار عزيزة }
\end{aligned}
$$

ب. الصفة المشبهة على وزن "افعل"

$$
\begin{aligned}
& \text { المؤنث } \underline{\text { البنت البيضاء }} \\
& \text { الطالبة السوداء }
\end{aligned}
$$$$
\text { المرأة الصراء }
$$$$
\text { السماء الزرقاء }
$$$$
\text { المزرعة الخضراء }
$$$$
\text { الفلاحة السمراء }
$$$$
\text { المدرسة العليا }
$$$$
\text { البنت العرجاء }
$$$$
\text { الطبقة الدنيا }
$$$$
\text { الجزيرة الوسطى. } 10
$$$$
\text { المذكر }
$$$$
\text { الولد الابيض }
$$$$
\text { الطالب الاسود }
$$$$
\text { الرجل الاصفر }
$$$$
\text { البحر الأزرق }
$$$$
\text { المنظر الأخضر }
$$$$
\text { الفلاح الأسمر }
$$

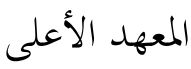

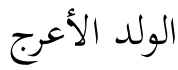$$
\text { المكان الأدنى }
$$$$
\text { الشرق الأوسط }
$$$$
\text { ج. الموصوف من الضمائر }
$$
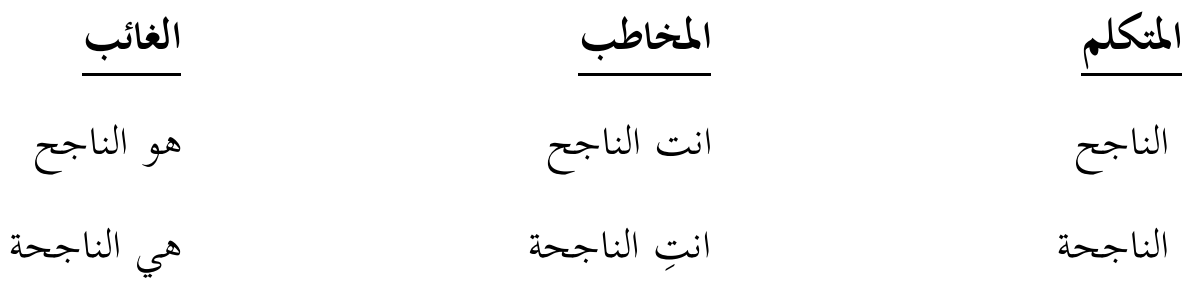

انا الناجح

انا الناجحة 287.

${ }^{9}$ Musțafā Muhammad Nūri, al- 'Arabiyah al-Muyassarah (Cet. I; Jakarta: Pustaka Arif, 2008), h. 285-

\footnotetext{
${ }^{10}$ Ibid., h. 288
} 
النعت والتو كيد

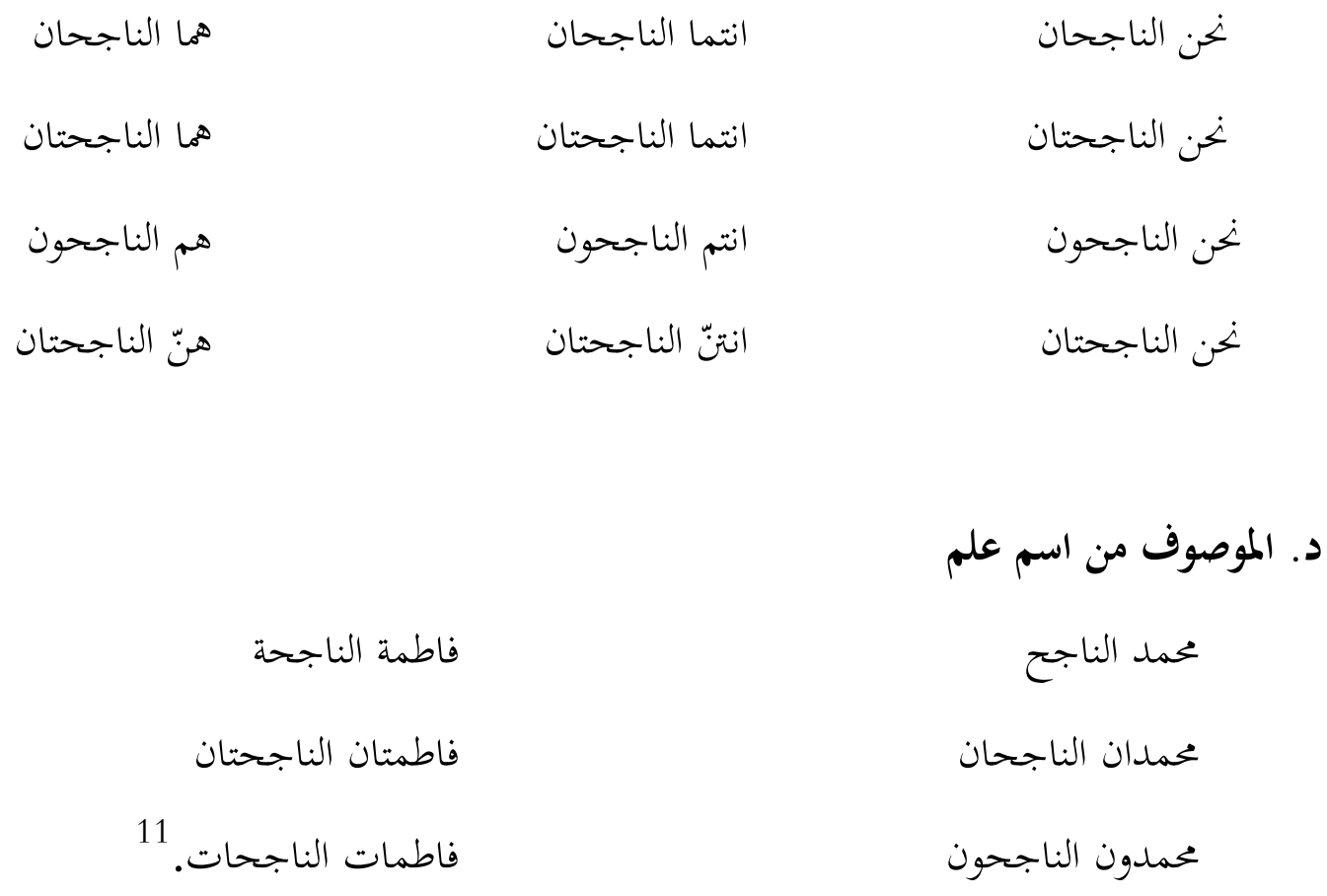

2. Syarat al-na'at (شرط النعت)

Asal atau dasar na'at adalah ism musytaq(isim yang mengalami perubahan). Seperti:

a. Ism fa'il( اسم فاعل ): الطالب الناجح (murid yang bersungguh-sungguh).

b. Ism maf'ul (اسم مفعول) (اسباب المفتوح (pintu yang terbuka).

c. Al-sifah al-musyabbahah(الكرسي الصغير:(الصفة المشبهة (kursi yang kecil). d.Yāu alnisbah (ياء النسبة) الطبيب الاندونسي (dokter Indonesia) berarti dokter yang berasal dari Indonesia. $^{12}$

Berbeda dengan Mustafa Muhammad Nuri, Musțafā al-Galāyainī memasukkan ism tafdil (اسم التفضيل) : سعيد تلميذ اعقل من غيره (ketua pelajar paling pintar dari yang lain). ${ }^{13}$

Jika na'at adalah ism jamid (beku, tidak mengalami perubahan) maka, ada 9 bentuk:

a. Al-masdar (المصدر) contoh, انت رجل عدل اي عادل (kamu seorang laki-laki adil, bermakna yang adil).

b. Ism isyarah (اسم الأشارة) contoh, اكرم عليا هذا اي المشار اليه (muliakan Ali ini, bermakna muliakan Ali yang ini).

${ }^{11}$ Ibid., h. 290

${ }^{12}$ Musțafā Muḥamad Nūri, al- 'Arabiah al-Muyassarah (Cet. I: Jakarta; Pustaka Arif, 2008), h. 289

${ }^{13}$ Mustafāā al-Galāyainī, lot. cit. 
c. Dzu(ذو) atau dzāti (ذات) yang bermakna memiliki/mempunyai (صاحب) contoh, جاحو) رجل ذو علم (datang seorang laki-laki yang mempunyai ilmu).

d. Ism mausul yang diganti dengan al (اسم الموصول المقترن بال) contoh, جاء الرجل الذي اجتهد اي المجتهد (datang seorang laki-laki yang bersungguh-sungguh).

e. Menunjukkan berbilangnya yang disifati, contoh: جاء رجال اربعة اي معدودون بهذا العدد (datang seorang laki-laki yang empat).

f. Ism yang menyerupai yāu al-nisbah (الاسم الذي لحقته ياء النسبة) contoh, رجلا رايت saya melihat seorang laki-laki Damaskus, bermakna yang bernasab/berketurunan Damaskus).

g. Menunjukkan penyerupaan (مادل على تشبية) contoh,رايت رجلا اسدا اي شجاعا) (saya melihat seorang laki-laki singa, bermakna yang keberaniannya seperti singa).

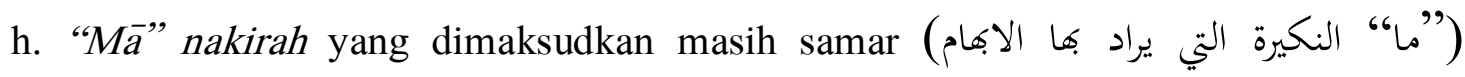
contoh, اكريمٌ رجلاً ما اي رجلا مطلقا غير مقيد بصفة ما

(dimuliakan seseorang yang....bermakna dimutlakkan tidak terikat dengan sifat).

i. Menggunakan dua kata 'kulii wa iyyi (كل وايّ) keduanya menunjukkan atas انت رجلُ كلُّ الرجلِ اي الكامل kesempurnaan yang disifati bagi sifat, contoh فيالرجولية (kamu seorang laki-laki yang kelaki-lakian). ${ }^{14}$

\section{Pembagian al-na'at}

Al-na'at terbagi kepada dua bagian, yaitu :

النعت الحقيقي: هو الذي ينعت اسما سابقا عليه، وينعت في كل شيء في التذكير و التأنيث و في

التعريف والتنكير و في الأفراد والتنية والجمع. نحو،نجح الطالب الجنتهد. 15 اذا كان النعوت جمع مذكر غير عاقل، فان نعته يجوز ان يكون مفردا مؤنثا و جمع مؤنث سالما و جمع تكسير مؤنثا، مثل: هذه بيوتُّ عاليةٌ (مفردا مؤنثا).

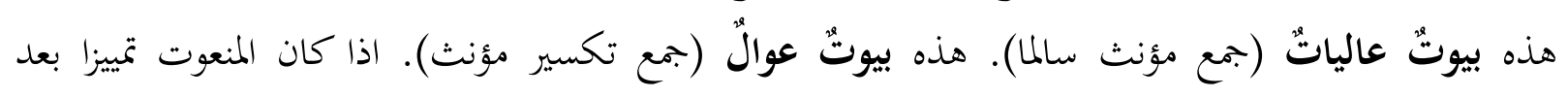

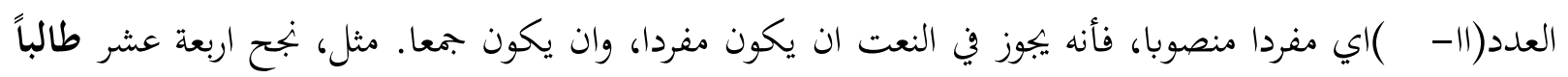
مجتهداً. نجح اربعة عشر طالبا مجتهدين. 16 فالحقيقي: ما يبيّن صفة من صفات متبوعه. نحو، جاء خالدُ الأديبُ. الأديب بين صفة متبوعه.هو

\footnotetext{
${ }^{14}$ Musțafāa Muḥammad Nưri, op. cit., h. 223

15،Abduh al-Rājihịi, op. cit., h. 373

${ }^{16}$ Ibid., h. 374

${ }^{17}$ Musțafā Muhammad Nūri,op. cit., h. 224
} 
النعت والنو كيد

اما النعت الحقيقي: مارفع ضميرا مستترا يعود الى المنعوت. نحو، جاء محمدُ العاقلُ. فالعاقل: نعت

18 لمحمد، وهو رفع لضمير مستتر تقديرهو يعود الى محمد.

اما النعت السبي: ما رفع اسما ظاهرا متصلا بضمير يعود الى المنعوت. نحو، جاء محمد الفاضل ابوه.

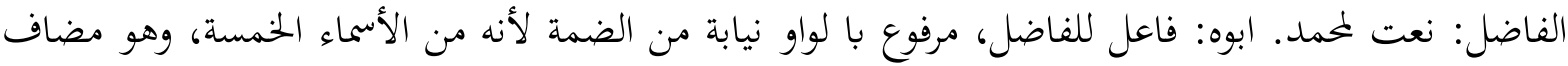
للى الهاء التي هي ضمير عائد المى محمد 19.

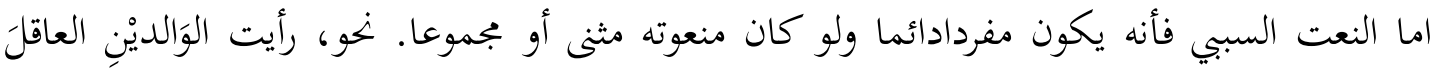

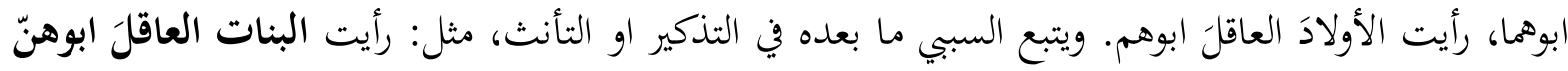
(saya telah melihat bapaknya anak-anak perempuan yang berakal). النعت السبي: وهو لاينعت الاسم السابق عليه على وجه الحقيقة، ولكنه ينعت اسما ظاهرا يأتى بعده، ويكون مرفوعا مشتملا على ضمير يعود على الاسم السابق، وهذا الاسم الأخير هو الذي يسمى السبى لأنه

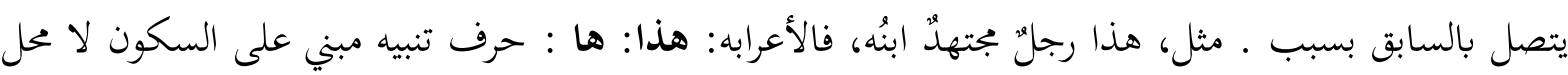

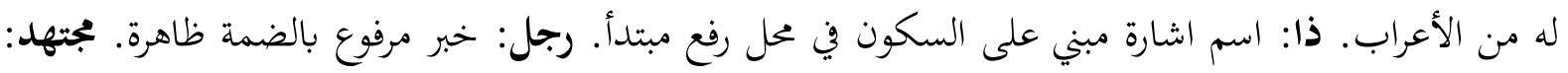

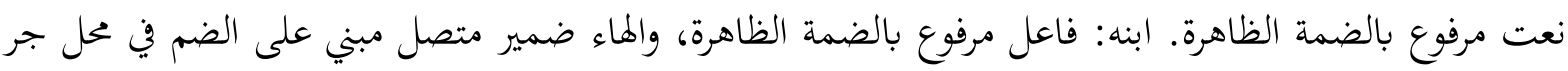
مضاف اليه. 21

\section{B. Al-Taukid}

1. Pengertian

التوكيد او التأكيد: تكرير يراد به تنبيتُ امرِ المكرَّرِ في النفس السامع، نخو، جاء علي نفسه. جاء عليُّ 22 عليُ2.

التوكيد هو تابع للموكّد في رفعه ونصبه وخفضه وتعريفه. التوكيد معناه في اللغة : التقوية. 23

$$
\text { التوكيد هو يتبع الاسمَ الموّمّدَ في اعرابه (رفعه، نصبه، وجرّهة). }
$$

2. Pembagian al-Taukid

Al-Taukid terbagi dua bagian, yaitu:

${ }^{18 ،}$ 'Abduh al-Rājiḥī, lot. cit.

${ }^{19}$ Muhammad 'Abd al-Raḥīm 'Ads, lot. cit.

${ }^{20}$ Muhammad Maḥy al-Dīn 'Abd al-Ḥamīd, op. cit., h. 108

${ }^{21}$ Mustafāā Muhammad Nūri, lot. cit.

${ }^{22}$ Musțafā Muhammad Nūri, op. cit., h. 231

${ }^{23}$ ،Abduh al-Rājihịi, op. cit., h. 120

${ }^{24}$ Muhammad Maḥy al-Din 'Abd al-Ḥamìd, op. cit., h. 200 
التوكيد اللفظي هو تكرار المؤكد بلفظه، او بما في معناه. مثل الأجتهاد الأجتهاد طريق النجاح. الأجتهاد: مبتدأ مرفوع بالضمة الظاهرة. الأجتهاد: توكيد لفظي مرفوع بالضمة الظاهرة. 25

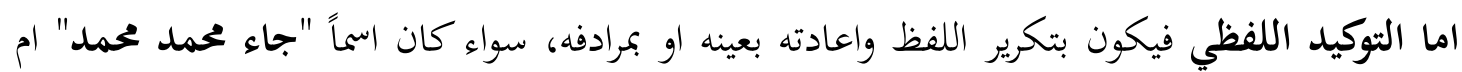
كان فعلاً "جاء جاء محّمد" ام كان حرفاً "نعم نعم جاء محمد". 26

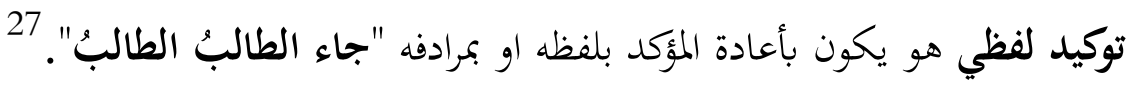

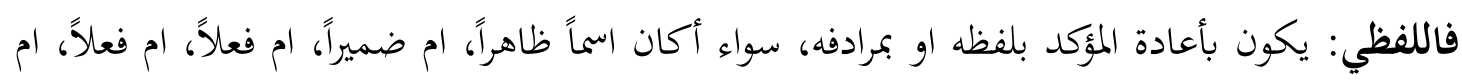

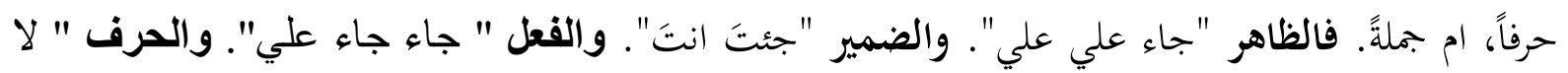

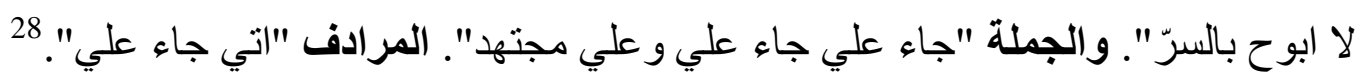

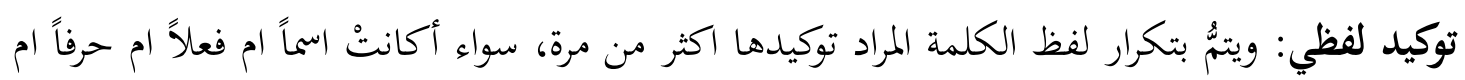

انّ التوكيد اللفظي هو تكرار معني المؤكد: بأعادة لفظه، او تقويته بمرادفه، لفصل التقرير، خوفا من النسيان، او عدم الأصفاء، او الاعتناء.

توكيد معنوي: يكون بذكر النفسِ او العين او جميع او عامة او كلا اوكلتا، على شرط ان تضاف هذه

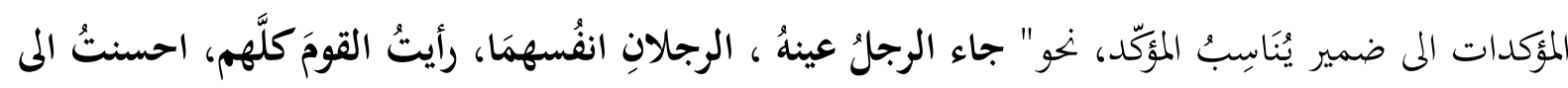

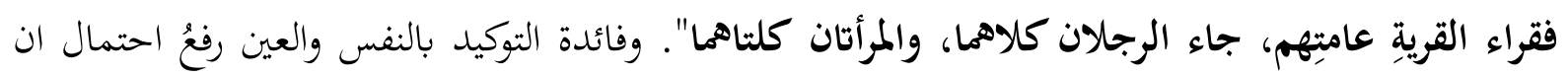

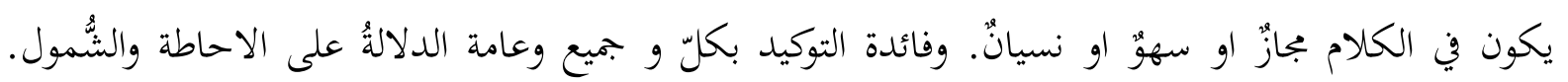

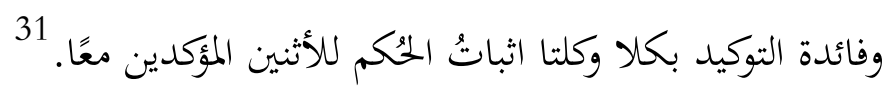

اما التوكيد المعنوي فهو التابع الذي يرفع احتمال السهو او التّجوز في المتبوع، فانّك لو قلتُ "جاء

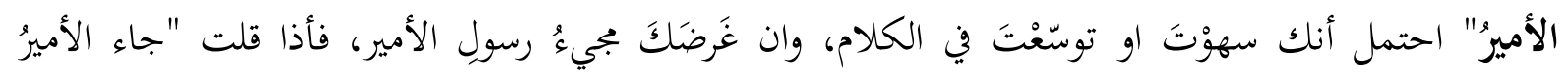

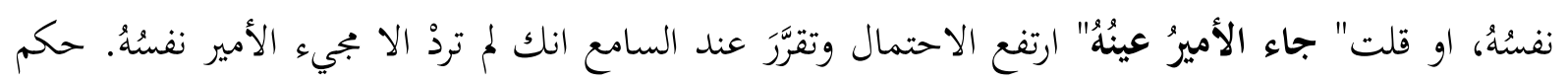

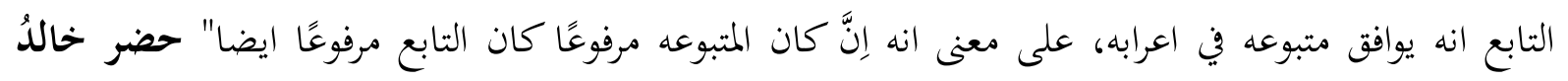

\footnotetext{
${ }^{25}$ Mustafāa al-Galāayainì, op. cit., h. 381

26، Abduh al-Rājihịi, lot. cit.

${ }^{27}$ Muhammad Mạ̣y al-Dīn 'Abd al-Ḥamīd, op. cit., h. 217

${ }^{28}$ Musțafā Muḥammad Nūri, op. cit., h. 232

${ }^{29}$ Muhammad 'Abd al- Rahīm 'Ads, lot. cit.

${ }^{30}$ Abū Abdullah Badr al-Dīn Muhammad, Syarh alfiyah Ibnu Malik (Beirut; Dār al-Jili, t.th), h. 509

${ }^{31}$ Mustafāa Muhammad Nūri, op. cit., h. 233
} 
نفسُهُ " وان كان المتبوع منصوبًا كان التابع منصوبًا "حفظْتُ القرأنَ كلَّهُ " وان كان المتبوع مخفوضًا كان التابع مخفوضًا "تدبَّتُ في الكتابِ كلِّهِ " ويتبعه ايضا في تعريفه. 32

التوكيد المعنوي: تستعمل الألفاظ نفس، عين، كلا، كلتا، جميع، عامة. وهذه الألفاظ يجب ان يسبقها

المؤكد الذي ينبغي ان يكون معرفة، وان تطابق في الأعراب، وان تضاف الى ضمير يعود الى المؤكد. جاء زيدُ نفسُهُ ، رأيت زيدا نفسَهُ ، مررت بزيدِ نفسِهِ. كلمة (نفس) في المثال الأول توكيد مرفوع بالضمة، وفي الثاني توكيد منصوب بالفتحة وفي الثالث توكيد بجرور بالكسرة. يجوز التوكيد بالنفس والعين بعد حرف جر زائد"جاء زيد بنفسه"

تستعمل كلا وكلتا لتوكيد المثنى "حضر الأستاذان كلاهما، رأيت الأستدين كليهما، مررت بالأستاذين

تستعمل الفاظ كل، جميع، عامة لتوكيد الشمول "قرأت الكتاب كلَّه، نجح الجنتهدون كلُهم، كافأت

المجتهدين كلَّهم، أعجبت باللاعبين جميعِهم، حضر الطلاب عامتُهم. ولكن اذا استعملت كلمة 'جميعا' دون ضمير يعود الى المؤكد لا تعرب توكيدا، بل تعرب حالاً"حضر الطلاب جميعا". جميعا: حال منصوب بالفتحة الظاهرة.

الفاظ أخرى تفيد توكيد الشمول، وتستعمل في الأغلب بعد كلمة 'كل' وهذه الألفاظ هي 'اجمع 'قرأت

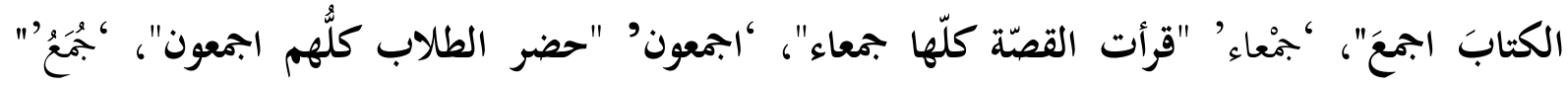

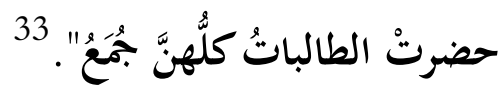

\section{KESIMPULAN}

1. Al-na'at bermakna sifat dan ada yang disifati (man'ut)

2. Al-na'at terjadi pada mufrad, jumlah dan syibh al-jumlah

3. Syarat al-na'at (شرط النعت). Jika na'at adalah ism musytaq(isim yang mengalami perubahan). Seperti: Ism fa'il( اسم فاعل ) . Ism maf'ul (اسم مفعول). Al-sifah almusyabbah(الصفة المشبهة). Yāal-nisbah (ياء النسبة). Ism tafḍil(اسم التفضيل)

4. Jika na'at adalah ism jamid (beku, tidak mengalami perubahan) maka, ada 9 bentuk: Al-masdar (اسم الأشارة) Ism isyarah). Dzu (ذور) atau dzăti (ذو) yang

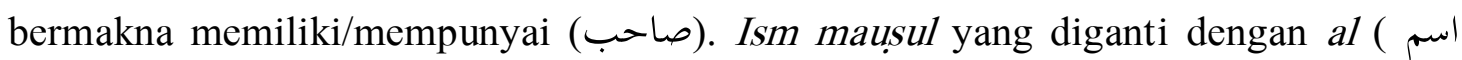
(الموصول المقترن بال. Menunjukkan berbilangnya yang disifati. Ism yang menyerupai yā

\footnotetext{
${ }^{32} \mathrm{Abu}$ Abdullah Badr al-Dìn Muhammad, lot. cit.

33 'Abduh al-Rājihịi, op. cit., h. $37 \dot{8}$
} 
al-nisbah (الاسم الذي لحقته ياء النسبة). Menunjukkan penyerupaan (مادل على تشبيه). "Mă̄" nakirah yang dimaksudkan masih samar ("ماك،" النكيرة التي يراد بها الابكام").Menggunakan dua kata 'kulii wa iyyi (كل وايّ) keduanya menunjukkan atas kesempurnaan yang disifati bagi sifat.

5. Al-na'at pada ism marfu, diserupakan dengan timbangan af'al, dan al na'at pada damir dan ism 'alam.

6. Al-na'at terbagi atas dua bagian yaitu na'at haqiqqi dan na'at sababī.

7. Al-taukìd bermakna penguatan

8. Al-taukid terbagi dua bagian yaitu taukid lafdzi dan taukid ma'nawi.

\section{DAFTAR PUSTAKA}

Al-Qur'ān al-Karim.

'Abd al-Hamīid, Muhammad Mahy al-Dīn. Al-Tahfah al-ŚSaniah bi Syarh al- $\quad$ Muqaddimah al-Jurumiyyah. Beirut; al-Maktabah al-'Așriyah, t. th

Al-Galayainī, Musțafā. Jämi' al-Durūs al- 'Arabiyah, juz. 3. Beirut: al-Maktabah al-'Așriyah, t.th.

Hāasan, 'Abbas. Al-Naḥw al-Wāfí, juz 3. Cet. IV; Mesir: Dār al-Ma'ārif, 1976.

Hassān, Abū Hani Tammām. al-Khulāṣah al-Naḥwiyyah. Cet. I; t.t.: 'Ālam al Kutub, 2000.

Al-Hāsyīmì, Ahmad. Al- Qawā'id al-'Asāsiyyah li al-Lugah al-'Arabiyyah. Beirut: Dār alFikr, $1354 \mathrm{H}$.

Mardan, Al-Qur'ān ( Sebuah Pengantar Memahami al-Qur'ān Secara Utuh). Cet. I: Makassar; Alauddin Press, 2009.

Muhammad, Abū 'Abdullah Badr al-Dỉn. Syarh alfiyah Ibnu Mālik. Beirut; Dār al-Jili, t. th. Nüri, Mustafāa Muhammad. Al- 'Arabiyah al-Muyassarah. Cet. I: Jakarta; Pustaka Arif, 2008.

Al-Raḥīm 'Ads, Muhammad 'Abd. Al-Wādih fī Qawāid al-Nahw wa al-Sarf. Cet. I: Amman; Daru Majdilawiy, 1991.

Al-Rājiḥị, Abduh. Al-Tațbiq al-Nahwī. Cet. I: Riyad; Maktabah al-Ma'ārif, 1999.

Mustafä, Ibrāhim. Ihyā' u al-Nahwï. Cet. II; Mesir: t.p, 1992.

Ni'mah, Fu'ād. Mulakhaș Qawā'id al-Lugah al-'Arabiyah, juz I. Beirut: Dār al-Saqafah alIslāmiyah, t.th. 